\title{
Methicillin-resistant Staphylococcus aureus in HIV-infected patients
}

This article was published in the following Dove Press journal:

Infection and Drug Resistance

5 August 2010

Number of times this article has been viewed

\section{Alicia I Hidron ${ }^{1,2}$ \\ Russell Kempker ${ }^{2}$ \\ Abeer Moanna ${ }^{1,2}$ \\ David Rimland ${ }^{1,2}$}

'Atlanta Veterans Affairs Medical Center, Decatur, GA, USA

${ }^{2}$ Department of Medicine, Division of Infectious Diseases, Emory University School of Medicine, Atlanta, GA, USA

Correspondence: Alicia Hidron VA Medical Center, RIM-I I I, 1670 Clairmont Rd., Decatur, GA 30033, USA

Tel + I-404-32 I-6 I I I (ext. 7592)

Fax + I-404-728-7782

Email ahidron@emory.edu
Abstract: Concordant with the emergence of methicillin-resistant Staphylococcus aureus (MRSA) in the community setting, colonization and infections with this pathogen have become a prevalent problem among the human immunodeficiency virus (HIV)-positive population. A variety of different host- and, possibly, pathogen-related factors may play a role in explaining the increased prevalence and incidence observed. In this article, we review pathophysiology, epidemiology, clinical manifestations, and treatment of MRSA in the HIV-infected population.

Keywords: MRSA, Staphylococcus aureus, HIV, resistance

\section{Introduction}

In persons infected with the human immunodeficiency virus (HIV), Staphylococcus aureus (S. aureus) infections account for significant morbidity. ${ }^{1-3}$ S. aureus was recognized to colonize the anterior nares of HIV-infected patients with greater frequency than that of the general population dating back to the 1990s, leading authors to postulate that this higher colonization burden might translate into a higher incidence of infections. ${ }^{4,5}$

Methicillin-resistant Staphylococcus aureus (MRSA) was first reported in the 1960s and started to establish itself as a nosocomial pathogen with increasing prevalence rates among hospitals nationally and worldwide. ${ }^{6,7}$ Originally associated only with health care-acquired infections, MRSA began to be recognized as an important cause of community-onset infections in the late $1990 \mathrm{~s}^{8}{ }^{8-10}$ Now recognized as communityacquired MRSA (CA-MRSA), the latter differs genotypically and phenotypically from health care-associated MRSA (HA-MRSA). CA-MRSA isolates carry much smaller staphylococcal cassettes (SCCmec types IV, V, or VII), ${ }^{11,12}$ have different lineages (the predominant lineages by multilocus sequence typing are sequence types ST80 and ST30 outside the United States ${ }^{13-15}$ and ST8 and ST1 in the United States), ${ }^{16,17}$ and carry the Panton Valentine leukocidin (PVL) gene (which encodes for a S. aureus toxin that creates pores on host cell membranes) $;{ }^{13}$ From a clinical standpoint, CA-MRSA isolates most commonly involve skin and soft tissues, ${ }^{16}$ tend to affect younger patients, ${ }^{18-23}$ and are characteristically susceptible to a greater number of non- $\beta$ lactam antibiotics. ${ }^{22,24}$ MRSA has thus established itself as a heterogeneous group of organisms with different epidemic potentials resulting in its constantly evolving epidemiology. This heterogeneity is also represented by different virulence potentials and complex interactions with susceptible hosts. HIV-infected patients are now recognized as one of these higher risk groups due to increased rates of both MRSA colonization and infections over the past decade. The organism's interactions and disease manifestations with 
the immunocompromised host are expected to be complex and diverse as the epidemiology of MRSA and that of HIV continue to change over time.

Herein, we review the pathophysiology, epidemiology, clinical manifestations, and treatment of MRSA in the HIV-infected population. It is important to note that specific issues related to colonization and infection may vary widely depending on the time period of the study, specific population studied, and the prevalence of antiretroviral treatment in the population, and to note that most of the available data are focused on CA-MRSA infections originating from North America where clonal group USA300 (ST8 by multilocus sequence typing) predominates.

\section{HIV and host defense against Staphylococcus aureus}

Innate immunity represents the main host defense against S. aureus, with neutrophils being the primary cellular defense of the innate immune response. ${ }^{25,26}$ Proper neutrophil function requires the coordination of many steps, including chemotaxis, phagocytosis, intracellular killing, and subsequent apoptosis. ${ }^{25}$ Although not as well studied as cellular or adaptive immunity, the innate immune response in persons with HIV have revealed significant neutrophil dysfunction that may increase the risk of bacterial infections.

Chemotaxis involves the active recruitment of neutrophils to the site of infection and is the first step in bacterial eradication. An early study evaluating neutrophil chemotaxis in persons with HIV found a more than $45 \%$ reduction in chemotaxis in persons with AIDS-related complex vs healthy controls. In addition, the serum from persons with HIV inhibited chemotaxis in neutrophils from the controls, ${ }^{27}$ suggesting that a serum molecule may be responsible for decreased chemotaxis in persons with HIV. In a subsequent study, the chemotactic index of neutrophils in children with asymptomatic HIV infection was $29.8 \%$ lower than that in healthy controls. ${ }^{28}$ In these studies, decreased chemotaxis was predominantly seen in persons with early HIV disease. One possible explanation is that increased cytokine expression in late-stage HIV may increase random neutrophil migration. ${ }^{28}$ In contrast to the more pronounced chemotaxis inhibition in early HIV disease described above, a longitudinal evaluation of neutrophil function in untreated HIV patients found an initial 19\% decrease in chemotaxis that progressed to a $32 \%$ decrease after 3 years of follow-up. ${ }^{29}$ In addition, the dysregulation of L-selectin expression (an adhesion molecule important in neutrophil binding to the endothelium) has been shown to increase with decreasing CD4 counts. ${ }^{30}$
Although data are limited, highly active antiretroviral treatment (HAART) may improve neutrophil chemotactic function. In a cohort of $18 \mathrm{HIV}$-infected persons with CD4 T-cell counts $<350 / \mu \mathrm{L}$ and diminished baseline neutrophil chemotaxis, chemotactic activity was found to be in the normal range in $72 \%$ after 9 months on HAART. ${ }^{31}$

After chemotaxis, neutrophil phagocytosis and intracellular killing are vital steps in host defense against $S$. aureus. ${ }^{25}$ Several studies have found decreased neutrophil phagocytosis of S. aureus in HIV-infected patients compared with healthy controls. ${ }^{32}$ Studies demonstrating reduced bacterial phagocytosis and respiratory burst with decreasing $\mathrm{CD} 4$ counts and a significantly increased capacity of neutrophils to phagocytose S. aureus in early HIV suggest that phagocytosis may depend on the stage of HIV infection. ${ }^{33,34}$ Paradoxically, no difference was found in the phagocytosis of $S$. aureus in asymptomatic and symptomatic HIV-infected patients vs controls, but phagocytosis by normal neutrophils was less efficient when bacteria were preopsonized with serum from HIV-infected persons, implying that defective opsonization may exist in HIV-infected persons. ${ }^{28}$ Studies have also shown a reduced bactericidal capacity of neutrophils in HIV-infected persons. A $>20 \%$ decrease in the intracellular killing of $S$. aureus was found in neutrophils from HIV-infected patients vs healthy controls. ${ }^{35}$ In contrast to studies that show impaired phagocytic oxidative capacity in HIV-infected patients may be explained by reduced intracellular bacterial killing, ${ }^{35-37}$ the impaired bactericidal capacity in this study was not explained by a defect in the production of reactive oxygen species. ${ }^{36}$ As is true for the defects in chemotaxis and phagocytosis, there is evidence that this decreased bactericidal activity of neutrophils against $S$. aureus in HIV-infected patients is more pronounced with late-stage HIV disease,,$^{27,28}$ and that bacterial killing by neutrophils from healthy controls can be decreased when S. aureus is pretreated with the serum of HIV patient, again revealing a possible defect of opsonization in patients with HIV. ${ }^{27,28}$ The effect of HAART on neutrophil bactericidal function is still unclear.

Neutropenia is a well-recognized consequence of HIV infection and increases the risk of bacterial infections. ${ }^{38}$ The etiology of neutropenia in HIV-infected persons is multifactorial with bone marrow invasion by opportunistic infections, treatment-related hematologic toxicities, and nutritional deficiency, all potentially playing a role. ${ }^{38}$ Another mechanism may be increased neutrophil apoptosis, which has been shown to be accelerated in HIV-infected persons. ${ }^{39-41}$ Pitrak et $\mathrm{al}^{40}$ found that neutrophil viability in culture was markedly decreased after 18 hours in 
patients with AIDS (58.8\%) vs healthy controls (83.5\%). ${ }^{40}$ It is believed the oxidative stress of HIV may, in part, be responsible for accelerated neutrophil death. ${ }^{41}$ Protease inhibitors (PIs) have been shown in vitro to inhibit neutrophil apoptosis, ${ }^{42}$ thus suggesting PI use may potentially reverse some of the accelerated neutrophil apoptosis seen in HIV-infected persons.

Many other cells play an important role in host defense against $S$. aureus, including monocytes and B lymphocytes. Monocytes are involved in the phagocytosis of bacteria, the production of immunomodulating cytokines (many of which direct and organize neutrophil function), and the removal of apoptotic neutrophils. Studies have shown significant monocyte dysfunction exists in HIV-infected patients. ${ }^{32,33,43}$ Moreover, the HIV Nef protein has been found to decrease monocyte chemotaxis and to inhibit the phagocytosis of apoptotic neutrophils, thus potentially contributing to an increased inflammatory state in HIVinfected persons. ${ }^{44,45}$

Finally, B lymphocytes produce antibodies that are an essential component of antibacterial immune responses and increase the efficiency of neutrophil phagocytosis. Since early on in the HIV epidemic, B-cell abnormalities and the production of dysfunctional antibodies have been recognized in HIV-infected persons and believed to increase the risk of bacterial infections. ${ }^{46,47}$

The demonstrated defects in innate immunity surely contribute to the high rates of $S$. aureus infections in persons infected with HIV. Further work is needed to evaluate the effect of HAART on the recovery of the innate immune response against $S$. aureus.

\section{Epidemiology and clinical manifestations Colonization}

The prevalence of colonization with $S$. aureus varies according to the population studied. Groups of patients with higher colonization rates have been identified, including patients with HIV infection. ${ }^{48-55}$ For MRSA, specifically, colonization rates of $0 \%-17 \%$ have been reported for HIV-positive outpatients and $17 \%-31 \%$ for inpatients (Table 1 ). HIV has been identified as an independent risk factor for determining colonization with MRSA. ${ }^{48,49,52,56}$ The reason for the higher colonization rates observed are unclear, but could include factors such as frequent contact with both health care and community settings and frequent exposure to antibiotics, leading to a greater likelihood of becoming colonized with resistant strains. Some authors argue that this increased susceptibility to colonization with $S$. aureus could be HIV-specific. ${ }^{57}$ Some of the risk factors for colonization among HIV-infected patients suggest immunologic and virologic control, as well as the use of prophylactic Bactrim might be important protective measures. ${ }^{51,52,58,59}$ However, higher colonization burdens have been shown for HIV-infected patients without evidence of immunosuppression, suggesting this association might be independent of CD4 T-lymphocyte counts. ${ }^{54}$ In addition, sociodemographic and behavioral factors might also play an important role in establishing higher colonization rates among this patient population. Table 2

Table I Prevalence of MRSA colonization in HIV-positive patients

\begin{tabular}{|c|c|c|c|c|c|}
\hline $\begin{array}{l}\text { Patient } \\
\text { population }\end{array}$ & $\begin{array}{l}\text { No. of } \\
\text { HIV-infected } \\
\text { patients }\end{array}$ & $\begin{array}{l}\text { Median CD4 count } \\
\text { of the cohort }\end{array}$ & $\begin{array}{l}\text { HIV patients colonized } \\
\text { with S. aureus, \% }\end{array}$ & $\begin{array}{l}\text { HIV patients colonized } \\
\text { with MRSA, \% }\end{array}$ & Reference \\
\hline Outpatient ${ }^{\mathrm{a}}$ & 100 & 450 & 49 & 2 & 157 \\
\hline 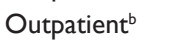 & 243 & NA & NA & 3.8 & 58 \\
\hline Outpatient $^{c}$ & 100 & NA & NA & 2 & 158 \\
\hline Outpatient $^{c}$ & 146 & 328 & NA & 10.3 & 59 \\
\hline Outpatient $^{c}$ & 158 & NA & 27 & 4 & 65 \\
\hline Outpatient $^{c}$ & 163 & NA & 21.5 & 3.1 & 159 \\
\hline Outpatient $^{c}$ & 195 & 270 & 23 & 3 & 160 \\
\hline Outpatient $^{c}$ & 111 & NA & $64.6^{d}$ & 0 & 55 \\
\hline Outpatient $^{c}$ & 900 & NA & NA & 8 & 79 \\
\hline In/outpatient ${ }^{c}$ & 178 & NA & NA & 34.8 & 161 \\
\hline Outpatient & 162 & 205 & 30 & 6 & 51 \\
\hline Outpatient $\mathrm{t}^{\mathrm{e}}$ & 60 & NA & 76.7 & 17.4 & 162 \\
\hline Outpatient $^{f}$ & 107 & 612 & $58.9^{d}$ & $16.8^{d}$ & 54 \\
\hline Inpatient & 81 & NA & NA & 17 & 48 \\
\hline Inpatient ${ }^{8}$ & 239 & NA & NA & 31.4 & 53 \\
\hline
\end{tabular}

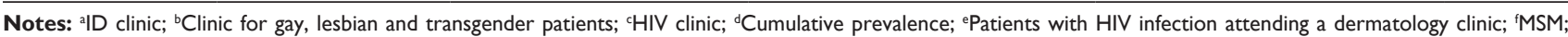
${ }^{8}$ Children admitted to a hospital in South Africa with pneumonia.

Abbreviations: MRSA, Methicillin-resistant Staphylococcus aureus; HIV, human immunodeficiency virus; NA, not available; ER, emergency room. 
Table 2 Risk factors for colonization with MRSA in HIV-positive patients $^{\mathrm{a}}$

\begin{tabular}{|c|c|}
\hline $\begin{array}{l}\text { Risk factors for colonization with } \\
\text { MRSA in HIV-positive patients } \\
\text { (reference) }\end{array}$ & $\begin{array}{l}\text { Studies that have } \\
\text { found no association } \\
\text { (reference) }\end{array}$ \\
\hline High HIV viral load ${ }^{58}$ & 54,159 \\
\hline Low CD4 T-cell count ${ }^{51,52,58,59,79}$ & $54,55,159,160$ \\
\hline Bactrim use (protective) $)^{58,59}$ & $160^{\mathrm{b}}$ \\
\hline \multicolumn{2}{|l|}{ Antibiotic use (other than } \\
\hline \multicolumn{2}{|l|}{ Bactrim) $)^{3,51,52,54,79,160}$} \\
\hline \multicolumn{2}{|l|}{ Hospitalization ${ }^{3,160}$} \\
\hline \multicolumn{2}{|l|}{ Central venous catheter ${ }^{3}$} \\
\hline \multicolumn{2}{|l|}{ Dermatologic disease $^{3}$} \\
\hline \multicolumn{2}{|c|}{$\begin{array}{l}\text { No significant association found for the following risk factors } \\
\text { (reference) }\end{array}$} \\
\hline \multicolumn{2}{|c|}{ Intravenous drug abuse (IVDU)/recreational drug use ${ }^{54,159}$} \\
\hline \multicolumn{2}{|l|}{ ARV treatment status ${ }^{54}$} \\
\hline \multicolumn{2}{|l|}{ Prior MRSA infections ${ }^{54}$} \\
\hline Use of sports/gym facilities/shared towels ${ }^{54}$ & \\
\hline
\end{tabular}

Notes: aDoes not take into account whether isolates are community-acquired MRSA (CA-MRSA) vs hospital-acquired MRSA (HA-MRSA); 'Use associated to risk, likely because their outpatient strain was identical to their hospital strain and therefore strain was likely a HA-MRSA strain.

Abbreviations: MRSA, Methicillin-resistant Staphylococcus aureus; HIV, human immunodeficiency virus; ARV, antiretroviral.

summarizes independent risk factors that have been identified for colonization with MRSA in HIV-positive patients.

Not all studies have found HIV status as an independent risk factor for colonization. ${ }^{60}$ Potential reasons to explain disagreement between studies include the presence of other unrecognized sites of colonization (patients might be colonized in the genital or perineal areas but not in the nasopharynx) ${ }^{61}$ and intermittent colonization. The intermittent nature of colonization is illustrated in the study by Shet et $a 1,{ }^{54}$ where the prevalence of MRSA colonization was $4.7 \%$ at the first visit, $8.7 \%$ at the second visit, and $11.8 \%$ at the third visit for a cumulative prevalence of $16.8 \%{ }^{54}$ It has been estimated that up to $20 \%$ of true carriers can be missed when a single sample is obtained. ${ }^{55}$ As far as persistence of colonization in HIV-infected patients who are known to be colonized, $38 \%-39 \%$ of patients have been reported to be persistent carriers, but up to $62 \%$ of patients will have a positive $S$. aureus nares culture if screened at three different points in time. ${ }^{55}$

Whether colonization with MRSA precedes MRSA infection is controversial. ${ }^{62}$ Earlier to widespread reports of CA-MRSA, a prospective, multicenter study found that HIV-infected patients colonized with $S$. aureus were more likely to become infected. ${ }^{63}$ In a study looking at patients not known to be HIV-infected with bacteremia, blood isolates matched nasal isolates in $82 \%$ of patients. ${ }^{64}$ Among HIVinfected patients, the study by Szumowski et a ${ }^{58}$ suggests an association between perianal MRSA colonization and skin and soft tissue infections (SSTIs). Pulsed-field gel electrophoresis (PFGE) profiles for infecting and colonizing strains in a recent study showed identical macrorestriction profiles. ${ }^{54}$ Furthermore, colonization with $S$. aureus has been identified as an independent risk factor for S. aureus infections in HIVpositive patients. ${ }^{54,63}$

In contrast, some published studies refute the role of prior colonization as necessary for MRSA infection. A point prevalence survey done in an HIV clinic reported that only 1 of 6 patients who had a MRSA SSTI during the previous 6 months was colonized with MRSA.${ }^{65}$ In this study, colonization at the time of infection was not assessed, so the absence of a temporal association is not certain. Similarly, in the case of MRSA bacteremia in HIV-infected children, S. aureus carriers did not have higher rates of $S$. aureus bacteremia than did noncarriers. ${ }^{53}$ Some authors have therefore suggested that high-risk sexual behavior may be a more important risk factor for transmission than actual colonization. ${ }^{66}$

\section{Infections}

Rates of MRSA infections have increased over time among HIV-positive patients ${ }^{66-70}$ and have been reported to be 6-fold to 18 -fold higher than in the general population. ${ }^{70,71}$ The proportion of MRSA relative to methicilin-susceptible S. aureus (MSSA) infections has also increased over the last several years among HIV-infected children and young adults (from $17 \%$ to $100 \%$ of all S. aureus infections at the end of an 8-year follow-up period). ${ }^{72}$ In retrospective reviews, $7 \%$ of outpatient HIV cohorts developed CA-MRSA infections over prolonged follow-up (8-13 years). ${ }^{69,70}$ Similarly, in an asymptomatic cohort of HIV outpatients followed over a year, $9 \%$ developed MRSA infections in contrast to $0 \%$ of the uninfected controls. ${ }^{54}$ In a dermatology practice over 3 years, $51 \%$ of CA-MRSA SSTIs were in HIV-positive patients. ${ }^{73}$ For SSTIs, specifically, the incidence of CA-MRSA among HIV-infected patients was reported to have significantly increased from 2000 to 2007 with USA300 MRSA accounting for $86 \%$ of the isolates. ${ }^{71}$ Not only HIV-positive patients are more likely to have community-onset $S$. aureus infections but also are more likely to have a nosocomial infection caused by $S$. aureus than HIV-negative patients. ${ }^{74}$

Whether HIV-infected patients are at increased risk of infections because of higher colonization rates or due to other social, environmental, behavioral, biologic, HIV host-specific risk factors, or a combination of all these is still unclear. Risk factors for MRSA infections have been more extensively studied for SSTIs in HIV-infected patients. Some authors 
postulate that CA-MRSA SSTIs are more tightly related with sexual behavior or drug-using behavior than they are with HIV. ${ }^{75,76}$ Evidence supporting the association with highrisk sexual practices includes a higher incidence of these infections in men who have sex with men (MSM), ${ }^{77}$ their distribution predominantly in the genital or perianal areas, ${ }^{70,75}$ the association with a history of other sexually transmitted diseases, ${ }^{70,75}$ and the protective use of condoms. ${ }^{75}$ It has also been suggested that the colonization patterns in CA-MRSA infection are different from those in non-CA-MRSA infections. ${ }^{78}$ This could offer a plausible explanation to the higher frequency of SSTI observed in this patient population, assuming a direct relationship with high-risk sexual practices.

Whether the risk for SSTI is increased among HIV patients with lower CD4 T-cell counts is debated: some studies have found a significant association, ${ }^{66,69,70,79}$ whereas others have not. ${ }^{58,75}$ Overall, reported mean CD4 counts at the time of presentation with SSTIs specifically have been well above 200 cells $/ \mathrm{mm}^{3}$ (mean CD4 counts: $457,{ }^{68} 445,{ }^{69}$ $560^{72}$ ). However, in favor of the role of immunosuppression, outbreaks have been reported in patients with extremely low CD4 counts (CD4 T-cell count $<10$ in $66 \%$ ), ${ }^{80}$ and $85 \%$ of $S$. aureus infections have been reported to occur in patients with CD4 counts less than 100 cells $/ \mathrm{mm}^{3}$ with this risk increasing over time. ${ }^{63}$

As would be expected, an elevated HIV viral load has been identified as a risk factor not only for infection ${ }^{66}$ but also for recurrence. ${ }^{69,81} \mathrm{Of}$ course, patients with higher degrees of immunosuppression are more likely to be in contact with the health care system, or, alternatively, immunosuppression might represent a marker for other associated conditions or behaviors. However, both low CD4 counts ${ }^{66,70,79,82}$ and elevated HIV viral load ${ }^{66,69,70}$ have been found to be independent risk factors for MRSA infections. Other risk factors for MRSA infections in HIV-positive patients are listed on Table 3.

\section{SSTI}

Mirroring what is observed in the general population, 3,58,66,72,75,76 most MRSA infections in HIV-positive patients represent SSTI, which account for up to $83 \%-90 \%$ of the MRSA infections observed in HIV outpatients, ${ }^{58,66,70}$ and $30 \%-45 \%$ in inpatients. ${ }^{3,82}$ Likewise, the etiology of SSTI in HIVinfected patients has been documented to be MRSA in $37 \%-93 \%$ of patients; $; 8,70,83$ the vast majority of these are due to CA-MRSA. ${ }^{70}$ In fact, the presence of a SSTI predicts infection with a specific clone identified by PFGE, the USA300 clone. ${ }^{79}$ The most common type of SSTIs are
Table 3 Risk factors for MRSA infections in HIV-positive patients

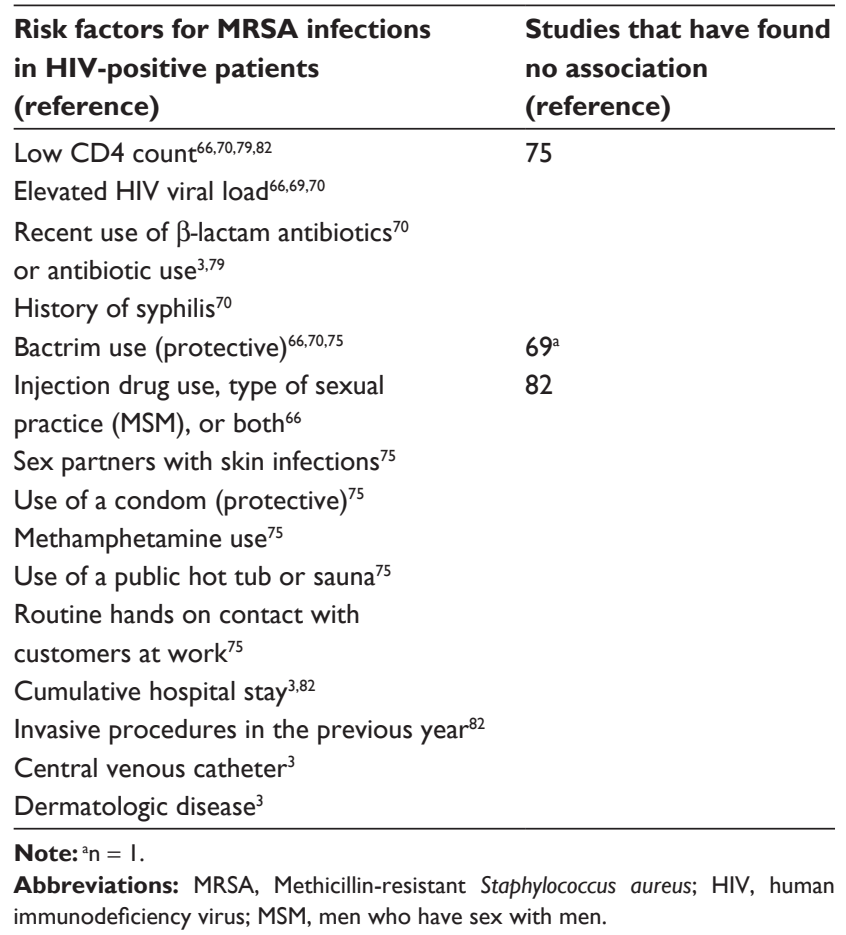

abscesses followed by cellulitis, furunculosis, impetigo, folliculitis, and carbuncles. ${ }^{70,75}$ Contrary to what would be expected, the majority of patients with MRSA SSTIs (specifically with CA-MRSA SSTIs) do not seem to have immunologic or virologic parameters consistent with AIDS at the time of infection. ${ }^{84}$ The location of SSTIs has been reported to be the lower extremity in $21 \%-32 \%$, buttocks/ scrotum/anogenital region in $26 \%-40 \%$, upper extremity in $10 \%-20 \%$, face in $3 \%-13 \%$, and trunk in $3 \%-10 \%{ }^{69,70,75}$ Infections usually resolve with treatment ${ }^{68}$ and are rarely complicated by pneumonia or osteomyelitis. ${ }^{72}$ Bacteremia is also an infrequent complication but has been reported in $0 \%-7 \%$ of patients..$^{68,70,72}$ The rates of patients requiring hospitalization are similar to those of the general population..$^{70} \mathrm{In}$ contrast, recurrence of infection is quite common $(10 \%-71 \%)$, which in some cases has been reported to occur at twice the rate of the general population. ${ }^{70}$ Recurrence usually occurs at a median of 4-4.5 months, ${ }^{68-70,72,76,81}$ and does not seem to be related to initial antibiotic susceptibility and antibiotics received for the initial SSTI; ${ }^{81}$ more frequently, recurrences happen at a different site of the original infection. ${ }^{72}$ Risk factors for recurrence include lower CD4 cell counts, higher HIV RNA levels, lack of incision and drainage at the time of initial MRSA infection, ${ }^{69}$ whereas risk factors for infection (specifically with a CA-MRSA isolate) include residence in alternative housing (ie, shelters), residence in high-risk zip codes, and younger age. ${ }^{71}$ 
Although the majority of reported SSTIs in HIV-infected patients are due to CA-MRSA, there are limited data with specific isolate typing or looking at the role of staphylococcal toxins that are known to be commonly associated with these isolates, such as PVL. ${ }^{85}$ Of the few studies for which typing is available, Skiest et $\mathrm{al}^{68}$ found $88 \%$ and $100 \%$ of MRSA isolates carried SCCmec type IV and PVL, respectively; Graber et al found $87 \%$ of all MRSA isolates were USA300 (which usually carries SCCmec type IV and PVL); ${ }^{17,81}$ and Ramsetty et al found that $89 \%$ of the MRSA isolates causing both infection and colonization in HIV outpatients were USA300. ${ }^{79}$ Srinivasan et $\mathrm{al}^{72}$ reported a lower prevalence of infections with the USA300 MRSA isolate (52\% PVL positive, USA300) among $31 \mathrm{HIV-infected} \mathrm{children} \mathrm{and} \mathrm{young} \mathrm{adults}$ with MRSA infections, $87 \%$ of which were SSTIs. Only this last study attempted to determine whether PVL-positive MRSA strains caused increased morbidity in the HIV-positive population compared with PVL-negative MRSA strains. In addition to finding that the proportion of patients with PVL-positive MRSA infections did not increase over time (despite the fact the proportion of overall MRSA infections did relative to MSSA), they found that PVL-positive MRSA infections were significantly associated with more SSTI but not with increased morbidity or a higher risk of complications compared with PVL-negative MRSA infection. ${ }^{72}$

\section{Invasive infections}

Cases of $S$. aureus or MRSA necrotizing cellulitis, pyomyositis, ${ }^{86}$ necrotizing fasciitis, ${ }^{87,88}$ pneumonia, ${ }^{2,3,89}$ bacteremia, ${ }^{3}$ endocarditis, ${ }^{63,88,90}$ purulent pericarditis with cardiac tamponade, ${ }^{91}$ and even perinephric abscess ${ }^{2}$ have all been reported in HIV-positive patients. With few exceptions, ${ }^{63,82}$ invasive infections (ie, bacteremia, endocarditis, pneumonia, etc) are not as common as SSTIs, usually accounting for $<20 \%$ of MRSA infections overall. ${ }^{3,66,70,72}$ Bacteremias have been reported to account for approximately 10\%-41\% of MRSA infections, pneumonias for 6\%-30\%, and deep soft tissue infections, endocarditis, and other invasive infections accounting for even lower percentages, but these numbers vary depending on the type of cohort (inpatient vs outpatient). ${ }^{66,82}$ Regardless, these deep-seated infections can be a significant cause of morbidity and mortality in this patient population. For HIV-positive patients with $S$. aureus bacteremia, for example, mortality rates of up to $67 \%$ have been reported and patients are twice as likely to die compared with HIV-positive patients without this invasive infection. ${ }^{63}$ The outbreak reported by Smith et al, ${ }^{15}$ additionally suggested that this increased morbidity and mortality might be related to immunosuppression because all cases occurred among patients with low CD4 counts $(67 \%$ with CD4 counts $<10)$ and $83 \%$ had invasive disease ( 3 of 6 patients with bacteremia and 2 of 6 with pneumonia). In contrast, despite finding a two fold increased mortality rate in HIV-positive patients with an MRSA infection compared with other HIV-positive inpatients, a study from Italy did not find this to be a statistically significant mortality difference. ${ }^{82}$

Whether improved HIV control will result in reduced risk of MRSA infections and/or recurrences is argued by some ${ }^{69}$ but remains to be proved in future studies.

\section{Bacteremia}

$S$. aureus is the most frequent cause of both community and hospital-acquired bacteremia in HIV-positive patients, ${ }^{2,92-94}$ and MRSA can explain $32 \%-67 \%$ of cases of $S$. aureus bacteremia in this patient population. ${ }^{2,67,82,95-97}$ At large urban centers, the prevalence of HIV among patients with MRSA bacteremia can be up to $22 \% .{ }^{98}$ Prior to the widespread emergence of MRSA in the community, the incidence of MRSA bacteremia in HIV-positive patients was thought to be declining. ${ }^{95}$ Burkey et $\mathrm{al}^{67}$ reported an increasing incidence just a few years later. This recent increasing incidence temporally coincides with increasing reports of MRSA from the community.

After SSTIs, bacteremia is the most frequently observed infection among HIV-infected patients. Along with IVDA, ${ }^{67}$ end-stage renal disease, ${ }^{67}$ low CD4 T-cell count $(<200$ cells/ $\mu \mathrm{L}),{ }^{67,95}$ use of $\beta$-lactam antibiotics, ${ }^{95}$ and previous hospital admissions, ${ }^{95} \mathrm{HIV}$ infection has been identified as an independent risk factor for MRSA bacteremia. ${ }^{99}$ Hospitalized patients with HIV have been reported to be almost 17 times more likely to have $S$. aureus bacteremia compared with HIV-negative patients. ${ }^{96}$

The source of bacteremia varies depending on the time the study was conducted and the patient population, perhaps in addition to other factors. In the pre-HAART era, cases of $S$. aureus bacteremia were more frequently communityacquired, reported among intravenous (IV) drug users, and commonly associated with endocarditis. ${ }^{2}$ In more recent studies (coinciding with widespread reports of CA-MRSA), the source for $S$. aureus bacteremia was somewhat different: SSTI in $15 \%-31 \%$ of cases, a catheter in $17 \%-54 \%$ of cases, use of IV drugs (or endocarditis) in 3\%-49\%, and unknown in approximately $19 \% .{ }^{96,97}$ Significant immunosuppression can be observed among patients with bacteremia, with mean CD4 counts at the time of bacteremia of $52-130$ cells $/ \mathrm{mm}^{3}$ and $94 \%$ of the patients being categorized as AIDS in one of the 
studies. ${ }^{96,97}$ Paradoxically, CD4 counts and viral loads have not been shown to be independent predictors for poor outcomes. In fact, the absence of HAART has been associated with a lower mortality. ${ }^{97}$ Whether outcomes of HIV-infected patients with $S$. aureus bacteremia are influenced by the isolate's resistance profile (MRSA vs MSSA) is another matter of debate: 2 studies suggest this is not the case, ${ }^{96,97}$ but a recent study suggests both HIV infection and methicillin resistance can increase at least the odds of $S$. aureus bacteremia recurrence by almost 5 and 2 times, respectively. ${ }^{100}$ Rates of objective outcomes, such as mortality, have not been found to be significantly higher in HIV-infected patients compared with HIV-negative patients with $S$. aureus bacteremia. ${ }^{101}$ In HIV-infected patients with $S$. aureus bacteremia, overall mortality rates are $10 \%-67 \%$, and approximately $40 \%$ for MRSA specifically. ${ }^{58,63,97,101}$

From a clinical standpoint, little data are available differentiating the clinical presentations of bacteremia in HIV-infected and uninfected patients. Mean duration of fever, percentage of bands, neutrophils, and number of platelets are similar between HIV-infected and uninfected patients with $S$. aureus bacteremia, but HIV-infected patients do have significantly lower white blood cell counts on admission. ${ }^{96}$ Complications of bacteremia may include metastatic seeding, pneumonia, endocarditis (which can be observed in up to $20 \%$ of patients), relapse or recurrence of infection (observed in up to $17 \%$ of patients), sepsis, shock, and overall can be observed in approximately $13 \%$ of patients..$^{96,97}$

\section{Endocarditis}

The most common etiologic agent of endocarditis among HIV-infected patients, whether IV drug users or not, is S. aureus..$^{90,102,103}$ The incidence, epidemiology, clinical presentation, and outcomes of infective endocarditis (IE) were evaluated in HIV-infected outpatients followed at one center. Though the study was not limited to cases with $S$. aureus, it was by far the most common etiologic organism representing $69 \%$ of the cases; of these, $28 \%$ were methicillinresistant. The incidence of IE in HIV-infected patients was found to be significantly higher than that of the general population. The majority of cases occurred among male, African-American IV drug users in their 40 years of age with median CD4 counts of 68 cells $/ \mathrm{mm}^{3}$. These demographics did not differ from HIV-infected controls without IE except for the following identified risk factors: IV drug use, CD4 count $<50$ cells $/ \mathrm{mm}^{3}$, and HIV RNA $>100,000$ copies $/ \mathrm{mL}^{9}{ }^{90}$ Fever, chills, shortness of breath, and myalgias were the most common presenting symptoms. Over $50 \%$ of the patients in this cohort had died at 1 year, but the type of organism was not found to be an independent predictor of mortality. At 1 year, $16 \%$ of patients had recurrences, and $66 \%$ of the recurrences were due to $S$. aureus..$^{90}$

A second study looking at 133 cases of $S$. aureus endocarditis (of whom 38\% were HIV-positive drug abusers) from one center over a 22-year period found that HIV-negative patients with $S$. aureus IE were more likely to have dyspnea, cutaneous signs, neurologic lesions, and even a higher mortality. This can be explained by the fact that HIV-positive patients were more likely to be drug abusers and therefore to have right rather than left-sided endocarditis, which is associated with a more favorable prognosis. ${ }^{104}$ Of note, only $6 \%$ of the isolates were methicillin-resistant. Reports of IE caused by CA phenotype isolates (ie, USA300) among HIV-positive patients are still limited. ${ }^{105}$

\section{Pneumonia}

As is the case for the general population, MRSA pneumonia among HIV-positive patients can be health-care associated, secondary to bacteremia, or community-acquired. MRSA is a common pathogen for nosocomial pneumonia in HIV-positive patients (25\% of cases due to $S$. aureus, $65 \%$ of these methicillin-resistant) and has been identified as an independent risk factor for mortality among HIVpositive patients. ${ }^{106} \mathrm{CA}-\mathrm{MRSA}$ pneumonia has been recognized as an emerging entity concurrent to the emergence of CA-MRSA, presenting usually after a viral prodrome with varying degrees of lung necrosis which manifest as shortness of breath, sepsis, and hemoptysis. ${ }^{107}$ It was initially recognized mainly among healthy patients, ${ }^{107}$ but in more recent reports, nearly $50 \%$ of the cases were among immunocompromised patients and $43 \%$ of the patients in this group were HIV-positive. ${ }^{89}$

\section{Necrotizing fasciitis}

Overall, $S$. aureus was an infrequent cause of necrotizing fasciitis but is now recognized as an emerging clinical syndrome. ${ }^{88}$ Of 19 cases of CA-MRSA necrotizing fasciitis reported in the literature, only $11 \%$ were HIV-positive patients. ${ }^{87}$ Data on the incidence and prevalence of this entity among HIV-positive patients are therefore limited to very few case reports, which impedes conclusions on comparative severity and clinical presentations. ${ }^{87,88}$ However, in general, it has been suggested that necrotizing fasciitis caused by CA-MRSA may be less virulent than similar infections caused by other organisms. ${ }^{88}$ 


\section{HIV and treatment of MRSA}

Little data suggest that the treatment of MRSA infections in HIV-infected patients should be any different than the treatment in noninfected patients. Below, we briefly review the limited data about treatment of these infections.

\section{Treatment of MRSA SSTIs}

A recent study in HIV-positive patients suggests that the antibiograms of MRSA isolates are showing lower susceptibility rates to antibiotics, such as clindamycin, erythromycin, and ciprofloxacin, to which MRSA isolates have classically been susceptible ${ }^{54}$ Concordant with this, a study looking at the MSM population in Boston and San Francisco found a high rate of resistance to clindamycin, tetracycline, and mupirocin among MRSA isolates independent of HIV infection. ${ }^{77}$ A similar study in MSM from New York reported a high rate of resistance to tetracycline (23\%), clindamycin (63\%), and erythromycin (93\%) in CA-MRSA isolates. ${ }^{108}$ In fact, recurrent infections with MRSA have been associated with resistance among initially susceptible isolates in $\mathrm{MSM}^{77}$ and in HIV-infected patients. ${ }^{69}$

A number of oral agents such as trimethoprimsulfamethoxazole (TMP-SMZ), clindamycin, tetracyclines such as doxycycline, rifampin (in combination with other agents), and linezolid have been used to treat MRSAassociated SSTIs in HIV and non-HIV patients. Despite the extensive use of the above-mentioned agents, there are no prospective controlled trials of most of these drugs prescribed to treat MRSA SSTIs. Small areas of skin infection with a drainable focus are usually cured by incision and drainage alone in adults ${ }^{17}$ and children. ${ }^{109,110}$ However, reported success to therapy has been $95 \%$ of patients with CA- MRSA SSTI who received an active antibiotic compared with $87 \%$ in those who did not. ${ }^{111}$ Large lesions, associated cellulitis, and presence of systemic symptoms like fever may warrant the use of a systemic antibiotic ${ }^{17,112}$ despite the lack of supporting evidence from prospective controlled trials. ${ }^{113}$ Addition of systemic antibiotics has also been advocated with advanced immunodeficiency. ${ }^{114}$

TMP-SMZ remains one of the most common drugs used to treat uncomplicated SSTIs due to MRSA despite the paucity of randomized, controlled trials that support its efficacy in such infections. TMP-SMZ was found to have a greater bactericidal activity against MRSA in vitro than linezolid, rifampicin, minocycline, and clindamycin ${ }^{115}$ and was considered as an acceptable alternative to vancomycin for the treatment of systemic MRSA infections by Markowitz et al. ${ }^{116}$ Increased rates of clinical response in SSTIs have been reported with the use of TMP-SMZ ${ }^{117}$ Clinicians should be aware that TMP-SMZ resistance among MRSA isolates in HIV-infected patients has been reported. ${ }^{50,118}$ The use of prophylactic TMP-SMZ may select for this resistance ${ }^{50,118,119}$ although resistance has also been reported without a history of prior TMP-SMZ use. ${ }^{70}$ Fortunately, overall TMP-SMZ resistance in HIV-infected patients remains infrequent. ${ }^{77}$

Clindamycin can potentially inhibit toxin production including PVL ${ }^{120,121}$ and is used to treat MRSA infections. ${ }^{122}$ Inducible clindamycin resistance has to be ruled out by performing a D-test because a number of isolates that are erythromycin-resistant have shown to be clindamycin-resistant despite appearing initially susceptible. ${ }^{123}$ The incidence of clindamycin resistance in the United States varies. In a study of SSTIs in HIV-infected patients in Dallas, 10\% of CA-MRSA isolates were resistant to clindamycin. ${ }^{68}$ Srinivasan et al ${ }^{72}$ reported a $19 \%$ incidence of clindamycin resistance in MRSA isolates from children and young adults with HIV infection at St. Jude Children's Research Hospital. A study of CA-MRSA SSTIs in MSM in New York has found that $63 \%$ of the isolates were resistant to clindamycin. ${ }^{108}$ Moreover, a more recent study of SSTIs in otherwise healthy HIV-positive patients in New York found that $42.9 \%$ of all MRSA isolates were resistant to clindamycin. ${ }^{54}$ Given the possible increasing rate of resistance of MRSA isolates, clindamycin should be used with caution if local antibiograms suggest local high-grade resistance of MRSA isolates.

Long-acting tetracyclines have been used to treat MRSAassociated infections. Clinical cure was achieved in $83 \%$ of patients with tetracycline-susceptible MRSA infections in a study by Ruhe et al. ${ }^{124}$ The same study found a similar response rate after review of the literature of 85 patients. ${ }^{124}$ Importantly, recent studies have found increasing resistance to tetracyclines among MRSA USA300 isolates in Boston and San Francisco. ${ }^{125,126}$

Linezolid is a bacteriostatic agent that can be given orally to treat MRSA SSTIs and is approved for that indication. One study found that linezolid was equivalent to vancomycin in treating complicated SSTIs. ${ }^{127}$ In a randomized trial treating diabetic foot infections, linezolid was at least as effective as aminopenicillin/ $\beta$-lactamase inhibitors. ${ }^{128}$ Resistance to linezolid has been reported, but it has not been a clinically significant problem to date. ${ }^{129}$ Linezolid, like clindamycin, can inhibit toxin production by MRSA isolates that may be helpful in the case of severe SSTIs. ${ }^{120}$ Linezolid use has been associated with myelosuppression, including thrombocytopenia and anemia, which are often reversible after drug discontinuation. ${ }^{130}$ Neurotoxicity, mainly 
peripheral and ocular neuropathy, has also been reported in patients receiving linezolid for more than 28 days. ${ }^{130-132}$

Finally, rifampin is sometimes used in combination with other agents although one study found the addition of rifampin to TMP-SMZ to be antagonistic. ${ }^{115}$

\section{Treatment of invasive infections}

Available parenteral agents for treatment of invasive MRSA infections, such as bacteremia, pneumonia and complicated SSTIs, include vancomyin, linezolid, daptomycin, tigecycline, and quinupristin-dalfopristin in HIV and non-HIV patients. Vancomycin has been the agent of choice for treating invasive MRSA infections for years. However, resistance among some MRSA isolates and poor tissue penetration of vancomycin have raised recent concern when treating severe MRSA infections. ${ }^{133-136}$ Moreover, there have been reports of treatment failure due to heteroresistant MRSA, in which a subpopulation of MRSA would have a high MIC and reduce susceptibility to vancomycin. ${ }^{137}$ In addition, there is a correlation between vancomycin minimum inhibitory concentrations (MICs) and treatment outcomes. ${ }^{138,139}$ Patients with MRSA bacteremia in one study had better outcomes when the isolates MIC was $0.5 \mu \mathrm{g} / \mathrm{mL}$ compared with those with $1-2 \mu \mathrm{g} / \mathrm{mL}$. ${ }^{138}$

Linezolid can be administered either orally or IV to patients with MRSA infections. In a randomized open-label trial of patients with presumed MRSA infections including SSTIs and pneumonia, the clinical cure rates were $73.2 \%$ and $73.1 \%$ in the linezolid group and the vancomycin group, respectively. ${ }^{140}$ Despite this, whether linezolid may be superior to vancomycin in the treatment of MRSA pneumonia is still controversial, and the optimal treatment of nosocomial and CA-MRSA pneumonia is not clearly defined due to the lack of prospective trials. ${ }^{141}$ Linezolid is not FDA approved for treatment of MRSA bacteremia or endocarditis. It has been used in such cases with some reports of success ${ }^{140,142}$ or failure, ${ }^{143,144}$ and its efficacy in treatment of MRSA bacteremia or endocarditis has yet to be established.

Daptomycin is a bactericidal drug that is FDA approved for treatment of $S$. aureus, including MRSA SSTI bacteremia, and right-sided endocarditis. Daptomycin had similar efficacy to vancomycin in treatment of patients with complicated SSTIs due to MRSA. ${ }^{145}$ In a randomized trial by Fowler et al ${ }^{146}$ in patients with $S$. aureus bacteremia with or without endocarditis, daptomycin was not inferior to standard therapy consisting of initial low-dose gentamicin with either antistaphylococcal penicillin or vancomycin. Importantly,
S. aureus isolates with heteroresistance to vancomycin may exhibit daptomycin nonsusceptibility despite the lack of previous exposure to daptomycin. ${ }^{147}$ Daptomycin should not be used for the treatment of MRSA pneumonia because the drug is inactivated by pulmonary surfactant causing clinical failures. ${ }^{148}$ Of note, daptomycin use has been associated with elevated creatine kinase, myopathy, and even rhabdomyolysis in some cases. ${ }^{146,149}$

Tigecycline is available as an IV drug for treatment of SSTIs, including MRSA SSTIs, and has been shown to be noninferior to vancomycin in some studies. ${ }^{150,151}$ However, its use has been limited, and the number of patients of MRSA infections receiving tigecycline has been small. In addition, cases of tigecycline-induced pancreatitis have been reported in the literature. ${ }^{152,153}$ Quinupristin-dalfopristin has been used for salvage therapy in MRSA infections in patients who are intolerant or failing standard therapy, ${ }^{154,155}$ but its use may be limited by the frequent adverse events, such as arthralgias and myalgias. ${ }^{156}$

In summary, several agents are available for treatment of SSTI and more serious infections due to MRSA, but few comparative studies are available and no studies have specifically evaluated the use of these agents in HIV-infected patients.

\section{Conclusion}

As the epidemiology of $S$. aureus (and MRSA specifically) continues to evolve, both colonization and infections with this organism have become increasingly common in the HIV-positive population. Behavioral, social, environmental, biologic, HIV host-specific risk factors, and, probably, a combination of all these play a significant role in explaining the increased prevalence and incidence observed. The organism's interactions with the immunocompromised host are complex, and involve defects in innate immunity.

Little data suggest that the treatment of MRSA infections in HIV-infected patients should be any different than the treatment in noninfected patients. Finally, whether improved HIV control will result in reduced risk of MRSA infections or recurrences remains to be proved in future studies.

\section{Acknowledgments}

This study was financially supported, in part, by the NIH Fogarty International Center (D43TW007124 and D43TW007124-06S1) and the Atlanta Clinical and Translational Science Institute (NIH/NCRR UL1RR025008) (Kempker). 


\section{Disclosure}

None of the authors in this manuscript have any conflicts of interest to disclose.

\section{References}

1. Jacobson MA, Gellermann H, Chambers H. Staphylococcus aureus bacteremia and recurrent staphylococcal infection in patients with acquired immunodeficiency syndrome and AIDS-related complex. Am J Med. 1988;85(2):172-176.

2. Witt DJ, Craven DE, McCabe WR. Bacterial infections in adult patients with the acquired immune deficiency syndrome (AIDS) and AIDSrelated complex. Am J Med. 1987;82(5):900-906.

3. Onorato M, Borucki MJ, Baillargeon G, et al. Risk factors for colonization or infection due to methicillin-resistant Staphylococcus aureus in HIV-positive patients: a retrospective case-control study. Infect Control Hosp Epidemiol. 1999;20(1):26-30.

4. Raviglione MC, Mariuz P, Pablos-Mendez A, Battan R, Ottuso P, Taranta A. High Staphylococcus aureus nasal carriage rate in patients with acquired immunodeficiency syndrome or AIDS-related complex. Am J Infect Control. 1990;18(2):64-69.

5. Weinke T, Schiller R, Fehrenbach FJ, Pohle HD. Association between Staphylococcus aureus nasopharyngeal colonization and septicemia in patients infected with the human immunodeficiency virus. Eur J Clin Microbiol Infect Dis. 1992;11(11):985-989.

6. Hidron AI, Edwards JR, Patel J, et al. NHSN annual update: antimicrobial-resistant pathogens associated with healthcare-associated infections: annual summary of data reported to the National Healthcare Safety Network at the Centers for Disease Control and Prevention, 2006-2007. Infect Control Hosp Epidemiol. 2008;29(11):996-1011.

7. Jones ME, Draghi DC, Thornsberry C, Karlowsky JA, Sahm DF, Wenzel RP. Emerging resistance among bacterial pathogens in the intensive care unit - a European and North American Surveillance study (2000-2002). Ann Clin Microbiol Antimicrob. 2004;3:14.

8. From the Centers for Disease Control and Prevention. Four pediatric deaths from community-acquired methicillin-resistant Staphylococcus aureus - Minnesota and North Dakota, 1997-1999. JAMA. 1999; 282(12):1123-1125.

9. From the Centers for Disease Control and Prevention. Methicillinresistant Staphylococcus aureus skin or soft tissue infections in a state prison - Mississippi, 2000. JAMA. 2002;287(2):181-182.

10. Outbreaks of community-associated methicillin-resistant Staphylococcus aureus skin infections - Los Angeles County, California, 2002-2003. MMWR Morb Mortal Wkly Rep. 2003;52(5):88.

11. Ma XX, Ito T, Tiensasitorn C, et al. Novel type of staphylococcal cassette chromosome mec identified in community-acquired methicillinresistant Staphylococcus aureus strains. Antimicrob Agents Chemother. 2002;46(4):1147-1152.

12. Ito T, Ma XX, Takeuchi F, Okuma K, Yuzawa H, Hiramatsu K. Novel type $\mathrm{V}$ staphylococcal cassette chromosome mec driven by a novel cassette chromosome recombinase, ccrC. Antimicrob Agents Chemother. 2004;48(7):2637-2651.

13. Vandenesch F, Naimi T, Enright MC, et al. Community-acquired methicillin-resistant Staphylococcus aureus carrying Panton-Valentine leukocidin genes: worldwide emergence. Emerg Infect Dis. 2003;9(8):978-984.

14. Tristan A, Bes M, Meugnier H, et al. Global distribution of PantonValentine leukocidin - positive methicillin-resistant Staphylococcus aureus, 2006. Emerg Infect Dis. 2007;13(4):594-600.

15. Smith JM, Cook GM. A decade of community MRSA in New Zealand. Epidemiol Infect. 2005;133(5):899-904.

16. King MD, Humphrey BJ, Wang YF, Kourbatova EV, Ray SM, Blumberg HM. Emergence of community-acquired methicillinresistant Staphylococcus aureus USA300 clone as the predominant cause of skin and soft-tissue infections. Ann Intern Med. 2006;144(5): 309-317.
17. Moran GJ, Krishnadasan A, Gorwitz RJ, et al. Methicillin-resistant $S$. aureus infections among patients in the emergency department. N Engl J Med. 2006;355(7):666-674.

18. CDC. Four pediatric deaths from community-acquired methicillinresistant Staphylococcus aureus, Minnesota and North Dakota, 19971999. MMWR Morb Mortal Wkly Rep. 1999;48:707-710.

19. CDC. Methicillin-Resistant Staphylococcus aureus Skin or Soft Tissue Infections in a State Prison, Mississippi, 2000. MMWR Morb Mortal Wkly Rep. 2001;50:919-922.

20. CDC. Methicillin-resistant Staphylococcus aureus infections among competitive sports participants: Colorado, Indiana, Pennsylvania, and Los Angeles County, 2000-2003. MMWR Morb Mortal Wkly Rep. 2003;52:793-795

21. Lindenmayer JM SS, O’Grady R, Carney JK. Methicillin-resistant Staphyloccus aureus in a high school wrestling team and the surrounding community. Arch Intern Med. 1998;158:895-899.

22. Naimi TS, LeDell KH, Como-Sabetti K, et al. Comparison of community- and health care-associated methicillin-resistant Staphylococcus aureus infection. JAMA. 2003;290(22):2976-2984.

23. Stacey AR, Endersby KE, Chan PC, Marples RR. An outbreak of methicillin-resistant Staphylococcus aureus infection in a rugby football team. Br J Sports Med. 1998;32(2):153-154.

24. Fridkin SK, Hageman JC, Morrison M, et al. Methicillin-resistant Staphylococcus aureus disease in three communities. $N$ Engl J Med. 2005;352(14):1436-1444.

25. DeLeo FR, Diep BA, Otto M. Host defense and pathogenesis in Staphylococcus aureus infections. Infect Dis Clin North Am. 2009;23(1):17-34.

26. Harrison CJ. Innate immunity as a key element in host defense against methicillin-resistant Staphylococcus aureus. Minerva Pediatr. 2009;61(5):503-514.

27. Ellis $M$, Gupta $S$, Galant $S$, et al. Impaired neutrophil function in patients with AIDS or AIDS-related complex: a comprehensive evaluation. J Infect Dis. 1988;158(6):1268-1276.

28. Roilides E, Mertins S, Eddy J, Walsh TJ, Pizzo PA, Rubin M. Impairment of neutrophil chemotactic and bactericidal function in children infected with human immunodeficiency virus type 1 and partial reversal after in vitro exposure to granulocyte-macrophage colony-stimulating factor. J Pediatr. 1990;117(4):531-540.

29. Flo RW, Naess A, Nilsen A, Harthug S, Solberg CO. A longitudinal study of phagocyte function in HIV-infected patients. AIDS. 1994; 8(6):771-777.

30. Elbim C, Prevot MH, Bouscarat F, et al. Polymorphonuclear neutrophils from human immunodeficiency virus-infected patients show enhanced activation, diminished fMLP-induced L-selectin shedding, and an impaired oxidative burst after cytokine priming. Blood. 1994;84(8):2759-2766.

31. Mastroianni CM, Lichtner M, Mengoni F, et al. Improvement in neutrophil and monocyte function during highly active antiretroviral treatment of HIV-1-infected patients. AIDS. 1999;13(8): 883-890.

32. Pos O, Stevenhagen A, Meenhorst PL, Kroon FP, van Furth R. Impaired phagocytosis of Staphylococcus aureus by granulocytes and monocytes of AIDS patients. Clin Exp Immunol. 1992;88(1):23-28.

33. Dobmeyer TS, Raffel B, Dobmeyer JM, et al. Decreased function of monocytes and granulocytes during HIV-1 infection correlates with CD4 cell counts. Eur J Med Res. 1995;1(1):9-15.

34. Bandres JC, Trial J, Musher DM, Rossen RD. Increased phagocytosis and generation of reactive oxygen products by neutrophils and monocytes of men with stage 1 human immunodeficiency virus infection. J Infect Dis. 1993;168(1):75-83.

35. Murphy PM, Lane HC, Fauci AS, Gallin JI. Impairment of neutrophil bactericidal capacity in patients with AIDS. J Infect Dis. 1988;158(3):627-630.

36. Hayani KC, Verral SC, Pitrak DL. Impaired phagocyte oxidative capacity in human immunodeficiency virus-infected children. J Infect Dis. 1999;179(3):584-589. 
37. Pitrak DL, Mullane KM, Bilek ML, Stevens P, Allen RC. Impaired phagocyte oxidative capacity in patients with human immunodeficiency virus infection. J Lab Clin Med. 1998;132(4):284-293.

38. Kuritzkes DR. Neutropenia, neutrophil dysfunction, and bacterial infection in patients with human immunodeficiency virus disease: the role of granulocyte colony-stimulating factor. Clin Infect Dis. 2000;30(2):256-260.

39. Salmen S, Teran G, Borges L, et al. Increased Fas-mediated apoptosis in polymorphonuclear cells from HIV-infected patients. Clin Exp Immunol. 2004;137(1):166-172.

40. Pitrak DL, Tsai HC, Mullane KM, Sutton SH, Stevens P. Accelerated neutrophil apoptosis in the acquired immunodeficiency syndrome. J Clin Invest. 1996;98(12):2714-2719.

41. Salmen S, Montes H, Soyano A, Hernandez D, Berrueta L. Mechanisms of neutrophil death in human immunodeficiency virus-infected patients: role of reactive oxygen species, caspases and map kinase pathways. Clin Exp Immunol. 2007;150(3):539-545.

42. Hadad N, Levy R, Schlaeffer F, Riesenberg K. Direct effect of human immunodeficiency virus protease inhibitors on neutrophil function and apoptosis via calpain inhibition. Clin Vaccine Immunol. 2007;14(11):1515-1521.

43. Noursadeghi M, Katz DR, Miller RF. HIV-1 infection of mononuclear phagocytic cells: the case for bacterial innate immune deficiency in AIDS. Lancet Infect Dis. 2006;6(12):794-804.

44. Pugliese A, Vidotto V, Beltramo T, Torre D. Phagocytic activity in human immunodeficiency virus type 1 infection. Clin Diagn Lab Immunol. 2005;12(8):889-895.

45. Torre D, Gennero L, Baccino FM, Speranza F, Biondi G, Pugliese A. Impaired macrophage phagocytosis of apoptotic neutrophils in patients with human immunodeficiency virus type 1 infection. Clin Diagn Lab Immunol. 2002;9:983-986.

46. Lane H, Masur H, Edgar LC, Whalen G, Rook AH, Fauci AS. Abnormalities of B-cell activation and immunoregulation in patients with the acquired immunodeficiency syndrome. $N$ Engl J Med. 1983;309(8):453-458.

47. Pahwa SG QM, Lange M, Pahwa RN, Grieco MH. Defective B-lymphocyte function in homosexual men in relation to the acquired immunodeficiency syndrome. Ann Intern Med. 1984;101(6) 757-763.

48. Hidron AI, Kourbatova EV, Halvosa JS, et al. Risk factors for colonization with methicillin-resistant Staphylococcus aureus (MRSA) in patients admitted to an urban hospital: emergence of communityassociated MRSA nasal carriage. Clin Infect Dis. 2005;41(2): $159-166$

49. Miller M, Cespedes C, Bhat M, Vavagiakis P, Klein RS, Lowy FD. Incidence and persistence of Staphylococcus aureus nasal colonization in a community sample of HIV-infected and -uninfected drug users. Clin Infect Dis. 2007;45(3):343-346.

50. Martin JN, Rose DA, Hadley WK, Perdreau-Remington F, Lam PK, Gerberding JL. Emergence of trimethoprim-sulfamethoxazole resistance in the AIDS era. J Infect Dis. 1999;180(6):1809-1818.

51. McDonald LC, Lauderdale TL, Lo HJ, Tsai JJ, Hung CC. Colonization of HIV-infected outpatients in Taiwan with methicillin-resistant and methicillin-susceptible Staphylococcus aureus. Int J STD AIDS. 2003;14(7):473-477.

52. Miller M, Cespedes C, Vavagiakis P, Klein RS, Lowy FD. Staphylococcus aureus colonization in a community sample of HIV-infected and HIV-uninfected drug users. Eur J Clin Microbiol Infect Dis. 2003;22(8):463-469.

53. McNally LM, Jeena PM, Gajee K, et al. Lack of association between the nasopharyngeal carriage of Streptococcus pneumoniae and Staphylococcus aureus in HIV-1-infected South African children. J Infect Dis. 2006;194(3):385-390.

54. Shet A, Mathema B, Mediavilla JR, et al. Colonization and subsequent skin and soft tissue infection due to methicillin-resistant Staphylococcus aureus in a cohort of otherwise healthy adults infected with HIV type 1. J Infect Dis. 2009;200(1):88-93.
55. Padoveze MC, de Jesus Pedro R, Blum-Menezes D, Bratfich OJ, Moretti ML. Staphylococcus aureus nasal colonization in HIV outpatients: persistent or transient? Am J Infect Control. 2008;36(3):187-191.

56. Sissolak D, Geusau A, Heinze G, Witte W, Rotter ML. Risk factors for nasal carriage of Staphylococcus aureus in infectious disease patients, including patients infected with HIV, and molecular typing of colonizing strains. Eur J Clin Microbiol Infect Dis. 2002;21(2):88-96.

57. Shapiro M, Smith KJ, James WD, et al. Cutaneous microenvironment of human immunodeficiency virus (HIV)-seropositive and HIV-seronegative individuals, with special reference to Staphylococcus aureus colonization. J Clin Microbiol. 2000;38(9):3174-3178.

58. Szumowski JD, Wener KM, Gold HS, et al. Methicillin-resistant Staphylococcus aureus colonization, behavioral risk factors, and skin and soft-tissue infection at an ambulatory clinic serving a large population of HIV-infected men who have sex with men. Clin Infect Dis. 2009;49(1):118-121.

59. Cenizal MJ, Hardy RD, Anderson M, Katz K, Skiest DJ. Prevalence of and risk factors for methicillin-resistant Staphylococcus aureus (MRSA) nasal colonization in HIV-infected ambulatory patients. J Acquir Immune Defic Syndr. 2008;48(5):567-571.

60. Holbrook KA, Klein RS, Hartel D, et al. Staphylococcus aureus nasal colonization in HIV-seropositive and HIV-seronegative drug users. J Acquir Immune Defic Syndr Hum Retrovirol. 1997;16(4):301-306.

61. Cook HA, Furuya EY, Larson E, Vasquez G, Lowy FD. Heterosexual transmission of community-associated methicillin-resistant Staphylococcus aureus. Clin Infect Dis. 2007;44(3):410-413.

62. Miller M, Cook HA, Furuya EY, et al. Staphylococcus aureus in the community: colonization versus infection. PLoS One. 2009;4(8):e6708.

63. Nguyen MH, Kauffman CA, Goodman RP, et al. Nasal carriage of and infection with Staphylococcus aureus in HIV-infected patients. Ann Intern Med. 1999;130(3):221-225.

64. von Eiff C, Becker K, Machka K, Stammer H, Peters G. Nasal carriage as a source of Staphylococcus aureus bacteremia. Study Group. NEngl J Med. 2001;344(1):11-16.

65. Rieg G, Daar E, Witt M, Guerrero M, Miller L. Community-acquired methicillin-resistant Staphylococcus aureus colonization among HIV-infected men who have sex with men: a point prevalence survey. Presented at 12th Confecerence on Retroviruses and Opportunistic Infections, Boston, MA, Feb 22-25; abstract 8772005.

66. Mathews WC, Caperna JC, Barber RE, et al. Incidence of and risk factors for clinically significant methicillin-resistant Staphylococcus aureus infection in a cohort of HIV-infected adults. J Acquir Immune Defic Syndr. 2005;40(2):155-160.

67. Burkey MD, Wilson LE, Moore RD, Lucas GM, Francis J, Gebo KA. The incidence of and risk factors for MRSA bacteraemia in an HIVinfected cohort in the HAART era. HIV Med. 2008;9(10):858-862.

68. Skiest D, Brown K, Hester J, et al. Community-onset methicillinresistant Staphylococcus aureus in an urban HIV clinic. HIV Med. 2006;7(6):361-368.

69. Crum-Cianflone N, Weekes J, Bavaro M. Recurrent community-associated methicillin-resistant Staphylococcus aureus infections among HIVinfected persons: incidence and risk factors. AIDS Patient Care STDS. 2009;23(7):499-502.

70. Crum-Cianflone NF, Burgi AA, Hale BR. Increasing rates of communityacquired methicillin-resistant Staphylococcus aureus infections among HIV-infected persons. Int J STD AIDS. 2007;18(8):521-526.

71. Popovich KJ, Weinstein RA, Aroutcheva A, Rice T, Hota B. CommunityAssociated Methicillin-Resistant Staphylococcus aureus and HIV: Intersecting Epidemics. Clin Infect Dis. 2010;50(7):979-987.

72. Srinivasan A, Seifried S, Zhu L, et al. Short communication: methicillin-resistant Staphylococcus aureus infections in children and young adults infected with HIV. AIDS Res Hum Retroviruses. 2009;25(12):1219-1224.

73. Iyer S, Jones DH. Community-acquired methicillin-resistant Staphylococcus aureus skin infection: a retrospective analysis of clinical presentation and treatment of a local outbreak. J Am Acad Dermatol. 2004;50(6):854-858. 
74. Padoveze MC, Trabasso P, Branchini ML. Nosocomial infections among HIV-positive and HIV-negative patients in a Brazilian infectious diseases unit. Am J Infect Control. 2002;30(6):346-350.

75. Lee NE, Taylor MM, Bancroft E, et al. Risk factors for communityassociated methicillin-resistant Staphylococcus aureus skin infections among HIV-positive men who have sex with men. Clin Infect Dis. 2005;40(10):1529-1534.

76. Bar A, Hantschke D, Mirmohammadsadegh A, Hengge UR. Spectrum of bacterial isolates in HIV-positive patients with skin and soft tissue infections: emergence of methicillin-resistant Staphylococci. AIDS. 2003;17(8):1253-1256.

77. Diep BA, Chambers HF, Graber CJ, et al. Emergence of multidrugresistant, community-associated, methicillin-resistant Staphylococcus aureus clone USA300 in men who have sex with men. Ann Intern Med. 2008;148(4):249-257.

78. Yang ES, Tan J, Eells S, Rieg G, Tagudar G, Miller LG. Body site colonization in patients with community-associated methicillin-resistant Staphylococcus aureus and other types of $S$. aureus skin infections. Clin Microbiol Infect. 2010;16(5):425-431.

79. Ramsetty SK, Stuart LL, Blake RT, Parsons CH, Salgado CD. Risks for methicillin-resistant Staphylococcus aureus colonization or infection among patients with HIV infection. HIV Med. 2010;11(6):389-394.

80. Smith NP, Nelson MR, Azadian B, Gazzard BG. An outbreak of methicillin-resistant Staphylococcus aureus (MRSA) infection in HIV-seropositive persons. Int J STD AIDS. 1998;9(12):726-730.

81. Graber CJ, Jacobson MA, Perdreau-Remington F, Chambers HF, Diep BA. Recurrence of skin and soft tissue infection caused by methicillinresistant Staphylococcus aureus in a HIV primary care clinic. J Acquir Immune Defic Syndr. 2008;49(2):231-233.

82. Drapeau CM, Angeletti C, Festa A, Petrosillo N. Role of previous hospitalization in clinically-significant MRSA infection among HIVinfected inpatients: results of a case-control study. BMC Infect Dis. 2007;7:36.

83. Krucke GW, Grimes DE, Grimes RM, Dang TD. Antibiotic Resistance in Staphylococcus aureus-containning cutaneous abscesses of patients with HIV. Am J Emerg Med. 2009;27:344-347.

84. Trinh TT, Short WR, Mermel LA. Community-associated methicillinresistant Staphylococcus aureus skin and soft-tissue infection in HIV-infected patients. J Int Assoc Physicians AIDS Care (Chic Ill). 2009;8(3):176-180.

85. Lina G, Piemont Y, Godail-Gamot F, et al. Involvement of PantonValentine leukocidin-producing Staphylococcus aureus in primary skin infections and pneumonia. Clin Infect Dis. 1999;29(5): 1128-1132.

86. Crum-Cianflone N. Increased Risk for MRSA Skin and Soft Tissue Infections Among HIV-Infected Persons. Available from http://www. medscape.com. Accessed Jan 27, 2010.

87. Olsen RJ, Burns KM, Chen L, Kreiswirth BN, Musser JM. Severe necrotizing fasciitis in a human immunodeficiency virus-positive patient caused by methicillin-resistant Staphylococcus aureus. J Clin Microbiol. 2008;46(3):1144-1147.

88. Miller LG, Perdreau-Remington F, Rieg G, et al. Necrotizing fasciitis caused by community-associated methicillin-resistant Staphylococcus aureus in Los Angeles. N Engl J Med. 2005;352(14):1445-1453.

89. Lobo LJ, Reed KD, Wunderink RG. Expanded clinical presentation of community-acquired MRSA pneumonia. Chest. Epub 2010 Feb 19.

90. Gebo KA, Burkey MD, Lucas GM, Moore RD, Wilson LE. Incidence of, risk factors for, clinical presentation, and 1-year outcomes of infective endocarditis in an urban HIV cohort. J Acquir Immune Defic Syndr. 2006;43(4):426-432.

91. Durao D, Fernandes AP, Marum S, Marcelino P, Mourao L. Cardiac tamponade secondary to methicillin-resistant Staphylococcus aureus pericarditis. Rev Port Cardiol. 2008;27(7-8):953-958.

92. Pedro-Botet ML, Modol JM, Valles X, et al. Changes in bloodstream infections in HIV-positive patients in a university hospital in Spain (1995-1997). Int J Infect Dis. 2002;6(1):17-22.
93. Krumholz HM, Sande MA, Lo B. Community-acquired bacteremia in patients with acquired immunodeficiency syndrome: clinical presentation, bacteriology, and outcome. Am J Med. 1989;86(6 Pt 2): 776-779.

94. Stroud L, Srivastava P, Culver D, et al. Nosocomial infections in HIV-infected patients: preliminary results from a multicenter surveillance system (1989-1995). Infect Control Hosp Epidemiol. 1997; 18(7):479-485.

95. Tumbarello M, de Gaetano Donati K, Tacconelli E, et al. Risk factors and predictors of mortality of methicillin-resistant Staphylococcus aureus (MRSA) bacteraemia in HIV-infected patients. J Antimicrob Chemother. 2002;50(3):375-382.

96. Senthilkumar A, Kumar S, Sheagren JN. Increased incidence of Staphylococcus aureus bacteremia in hospitalized patients with acquired immunodeficiency syndrome. Clin Infect Dis. 2001; 33(8):1412-1416.

97. Uche A, Forrest G. Staphylococcus aureus bacteremia in HIV-infected patients in the HAART era. Presented at 44th Annual Meeting of the Infectious Diseases Society of America (IDSA). Boston, MA, October $12-15 ; 2006$.

98. Seybold U, Kourbatova EV, Johnson JG, et al. Emergence of community-associated methicillin-resistant Staphylococcus aureus USA 300 genotype as a major cause of health care-associated blood stream infections. Clin Infect Dis. 2006;42(5):647-656.

99. Laupland KB, Ross T, Gregson DB. Staphylococcus aureus bloodstream infections: risk factors, outcomes, and the influence of methicillin resistance in Calgary, Canada, 2000-2006. J Infect Dis. 2008;198(3):336-343.

100. Kreisel K, Boyd K, Langenberg P, Roghmann MC. Risk factors for recurrence in patients with Staphylococcus aureus infections complicated by bacteremia. Diagn Microbiol Infect Dis. 2006; 55(3):179-184.

101. Perovic O, Koornhof H, Black V, Moodley I, Duse A, Galpin J. Staphylococcus aureus bacteraemia at two academic hospitals in Johannesburg. S Afr Med J. 2006;96(8):714-717.

102. Nahass RG, Weinstein MP, Bartels J, Gocke DJ. Infective endocarditis in intravenous drug users: a comparison of human immunodeficiency virus type 1-negative and -positive patients. $J$ Infect Dis. 1990;162(4):967-970.

103. Ribera E, Miro JM, Cortes E, et al. Influence of human immunodeficiency virus 1 infection and degree of immunosuppression in the clinical characteristics and outcome of infective endocarditis in intravenous drug users. Arch Intern Med. 1998;158(18):2043-2050.

104. Fernandez Guerrero ML, Gonzalez Lopez JJ, Goyenechea A, Fraile J, de Gorgolas M. Endocarditis caused by Staphylococcus aureus: a reappraisal of the epidemiologic, clinical, and pathologic manifestations with analysis of factors determining outcome. Medicine (Baltimore). 2009;88(1):1-22.

105. Tsai HC, Chao PJ, Sy CL, et al. Community-associated methicillinresistant Staphylococcus aureus infective endocarditis with PantonValentine leukocidin gene in an injection drug user with HIV infection. Intern Med. 2008;47(16):1485-1489.

106. Franzetti F, Grassini A, Piazza M, et al. Nosocomial bacterial pneumonia in HIV-infected patients: risk factors for adverse outcome and implications for rational empiric antibiotic therapy. Infection. 2006;34(1):9-16.

107. Hidron AI, Low CE, Honig EG, Blumberg HM. Emergence of community-acquired meticillin-resistant Staphylococcus aureus strain USA300 as a cause of necrotising community-onset pneumonia. Lancet Infect Dis. 2009;9(6):384-392.

108. Shastry L, Rahimian J, Lascher S. Community-associated methicillinresistant Staphylococcus aureus skin and soft tissue infections in men who have sex with men in New York City. Arch Intern Med. 2007;167(8):854-857.

109. Fergie JE, Purcell K. Community-acquired methicillin-resistant Staphylococcus aureus infections in south Texas children. Pediatr Infect Dis J. 2001;20(9):860-863. 
110. Lee MC, Rios AM, Aten MF, et al. Management and outcome of children with skin and soft tissue abscesses caused by communityacquired methicillin-resistant Staphylococcus aureus. Pediatr Infect Dis J. 2004;23(2):123-127.

111. Ruhe JJ, Smith N, Bradsher RW, Menon A. Community-onset methicillin-resistant Staphylococcus aureus skin and soft-tissue infections: impact of antimicrobial therapy on outcome. Clin Infect Dis. 2007;44(6):777-784.

112. Moellering RC Jr. Current treatment options for community-acquired methicillin-resistant Staphylococcus aureus infection. Clin Infect Dis. 2008;46(7):1032-1037.

113. Gorwitz RJ. The role of ancillary antimicrobial therapy for treatment of uncomplicated skin infections in the era of community-associated methicillin-resistant Staphylococcus aureus. Clin Infect Dis. 2007;44(6):785-787.

114. Ahuja D, Albrecht H. HIV and community-acquired MRSA. AIDS Clin Care. 2009;21(3):21-23.

115. Kaka AS, Rueda AM, Shelburne SA III, Hulten K, Hamill RJ, Musher DM. Bactericidal activity of orally available agents against methicillin-resistant Staphylococcus aureus. J Antimicrob Chemother. 2006;58(3):680-683.

116. Markowitz N, Quinn EL, Saravolatz LD. Trimethoprim-sulfamethoxazole compared with vancomycin for the treatment of Staphylococcus aureus infection. Ann Intern Med. 1992;117(5):390-398.

117. Szumowski JD, Cohen DE, Kanaya F, Mayer KH. Treatment and outcomes of infections by methicillin-resistant Staphylococcus aureus at an ambulatory clinic. Antimicrob Agents Chemother. 2007; 51(2):423-428.

118. Alonso R, Padilla B, Sanchez-Carrillo C, Munoz P, RodriguezCreixems M, Bouza E. Outbreak among HIV-infected patients of Staphylococcus aureus resistant to cotrimoxazole and methicillin. Infect Control Hosp Epidemiol. 1997;18(9):617-621.

119. Gordon RJ, Quagliarello B, Cespedes C, et al. A molecular epidemiological analysis of 2 Staphylococcus aureus clonal types colonizing and infecting patients with AIDS. Clin Infect Dis. 2005;40(7):1028-1036.

120. Stevens DL, Ma Y, Salmi DB, McIndoo E, Wallace RJ, Bryant AE. Impact of antibiotics on expression of virulence-associated exotoxin genes in methicillin-sensitive and methicillin-resistant Staphylococcus aureus. J Infect Dis. 2007;195(2):202-211.

121. Dumitrescu O, Boisset S, Badiou C, et al. Effect of antibiotics on Staphylococcus aureus producing Panton-Valentine leukocidin. Antimicrob Agents Chemother. 2007;51(4):1515-1519.

122. Daum RS. Clinical practice. Skin and soft-tissue infections caused by methicillin-resistant Staphylococcus aureus. $N$ Engl J Med. 2007;357(4):380-390.

123. Siberry GK, Tekle T, Carroll K, Dick J. Failure of clindamycin treatment of methicillin-resistant Staphylococcus aureus expressing inducible clindamycin resistance in vitro. Clin Infect Dis. 2003;37(9):1257-1260.

124. Ruhe JJ, Monson T, Bradsher RW, Menon A. Use of long-acting tetracyclines for methicillin-resistant Staphylococcus aureus infections: case series and review of the literature. Clin Infect Dis. 2005;40(10):1429-1434.

125. Diep BA, Carleton HA, Chang RF, Sensabaugh GF, PerdreauRemington F. Roles of 34 virulence genes in the evolution of hospital- and community-associated strains of methicillin-resistant Staphylococcus aureus. J Infect Dis. 2006;193(11):1495-1503.

126. Han LL, McDougal LK, Gorwitz RJ, et al. High frequencies of clindamycin and tetracycline resistance in methicillin-resistant Staphylococcus aureus pulsed-field type USA300 isolates collected at a Boston ambulatory health center. J Clin Microbiol. 2007;45(4): $1350-1352$.

127. Weigelt J, Itani K, Stevens D, Lau W, Dryden M, Knirsch C. Linezolid versus vancomycin in treatment of complicated skin and soft tissue infections. Antimicrob Agents Chemother. 2005;49(6): 2260-2266.
128. Lipsky BA, Itani K, Norden C. Treating foot infections in diabetic patients: a randomized, multicenter, open-label trial of linezolid versus ampicillin-sulbactam/amoxicillin-clavulanate. Clin Infect Dis. 2004;38(1):17-24.

129. Tsiodras S, Gold HS, Sakoulas G, et al. Linezolid resistance in a clinical isolate of Staphylococcus aureus. Lancet. 2001;358(9277): 207-208.

130. Vinh DC, Rubinstein E. Linezolid: a review of safety and tolerability. J Infect. 2009;59 Suppl 1:S59-S74.

131. Bressler AM, Zimmer SM, Gilmore JL, Somani J. Peripheral neuropathy associated with prolonged use of linezolid. Lancet Infect Dis. 2004;4(8):528-531.

132. Ferry T, Ponceau B, Simon M, et al. Possibly linezolid-induced peripheral and central neurotoxicity: report of four cases. Infection. 2005;33(3):151-154.

133. Stevens DL. The role of vancomycin in the treatment paradigm. Clin Infect Dis. 2006;42 Suppl 1:S51-S57.

134. Hiramatsu K, Aritaka N, Hanaki H, et al. Dissemination in Japanese hospitals of strains of Staphylococcus aureus heterogeneously resistant to vancomycin. Lancet. 1997;350(9092):1670-1673.

135. Tenover FC. Rapid detection and identification of bacterial pathogens using novel molecular technologies: infection control and beyond. Clin Infect Dis. 2007;44(3):418-423.

136. Sakoulas G, Moellering RC Jr. Increasing antibiotic resistance among methicillin-resistant Staphylococcus aureus strains. Clin Infect Dis. 2008;46 Supp1 5:S360-S367.

137. Charles PG, Ward PB, Johnson PD, Howden BP, Grayson ML. Clinical features associated with bacteremia due to heterogeneous vancomycin-intermediate Staphylococcus aureus. Clin Infect Dis. 2004;38(3):448-451.

138. Moise-Broder PA, Sakoulas G, Eliopoulos GM, Schentag JJ, Forrest A, Moellering RC Jr. Accessory gene regulator group II polymorphism in methicillin-resistant Staphylococcus aureus is predictive of failure of vancomycin therapy. Clin Infect Dis. 2004;38(12):1700-1705.

139. Hidayat LK, Hsu DI, Quist R, Shriner KA, Wong-Beringer A. Highdose vancomycin therapy for methicillin-resistant Staphylococcus aureus infections: efficacy and toxicity. Arch Intern Med. 2006; 166(19):2138-2144.

140. Stevens DL, Herr D, Lampiris H, Hunt JL, Batts DH, Hafkin B. Linezolid versus vancomycin for the treatment of methicillinresistant Staphylococcus aureus infections. Clin Infect Dis. 2002;34(11):1481-1490.

141. Skrupky LP, Micek ST, Kollef MH. Optimizing therapy for MRSA pneumonia. Semin Respir Crit Care Med. 2007;28(6):615-623.

142. Howden BP, Ward PB, Charles PG, et al. Treatment outcomes for serious infections caused by methicillin-resistant Staphylococcus aureus with reduced vancomycin susceptibility. Clin Infect Dis. 2004;38(4):521-528.

143. Ruiz ME, Guerrero IC, Tuazon CU. Endocarditis caused by methicillin-resistant Staphylococcus aureus: treatment failure with linezolid. Clin Infect Dis. 2002;35(8):1018-1020.

144. Sperber SJ, Levine JF, Gross PA. Persistent MRSA bacteremia in a patient with low linezolid levels. Clin Infect Dis. 2003;36(5): 675-676.

145. Arbeit RD, Maki D, Tally FP, Campanaro E, Eisenstein BI. The safety and efficacy of daptomycin for the treatment of complicated skin and skin-structure infections. Clin Infect Dis. 2004;38(12):1673-1681.

146. Fowler VG Jr, Boucher HW, Corey GR, et al. Daptomycin versus standard therapy for bacteremia and endocarditis caused by Staphylococcus aureus. $N$ Engl J Med. 2006;355(7):653-665.

147. Pillai SK, Gold HS, Sakoulas G, Wennersten C, Moellering RC Jr, Eliopoulos GM. Daptomycin nonsusceptibility in Staphylococcus aureus with reduced vancomycin susceptibility is independent of alterations in MprF. Antimicrob Agents Chemother. 2007;51(6):2223-2225.

148. Silverman JA, Mortin LI, Vanpraagh AD, Li T, Alder J. Inhibition of daptomycin by pulmonary surfactant: in vitro modeling and clinical impact. J Infect Dis. 2005;191(12):2149-2152. 
149. Papadopoulos S, Ball AM, Liewer SE, Martin CA, Winstead PS, Murphy BS. Rhabdomyolysis during therapy with daptomycin. Clin Infect Dis. 2006;42(12):e108-e110.

150. Breedt J, Teras J, Gardovskis J, et al. Safety and efficacy of tigecycline in treatment of skin and skin structure infections: results of a double-blind phase 3 comparison study with vancomycin-aztreonam. Antimicrob Agents Chemother. 2005;49(11):4658-4666.

151. Stein GE, Craig WA. Tigecycline: a critical analysis. Clin Infect Dis. 2006;43(4):518-524.

152. Lipshitz J, Kruh J, Cheung P, Cassagnol M. Tigecycline-induced Pancreatitis. J Clin Gastroenterol. 2009;43(1):93.

153. Hung WY, Kogelman L, Volpe G, Iafrati M, Davidson L. Tigecyclineinduced acute pancreatitis: case report and literature review. Int $J$ Antimicrob Agents. 2009;34(5):486-489.

154. Drew RH, Perfect JR, Srinath L, Kurkimilis E, Dowzicky M, Talbot GH. Treatment of methicillin-resistant staphylococcus aureus infections with quinupristin-dalfopristin in patients intolerant of or failing prior therapy. For the Synercid Emergency-Use Study Group. J Antimicrob Chemother. 2000;46(5):775-784.

155. Loeffler AM, Drew RH, Perfect JR, et al. Safety and efficacy of quinupristin/dalfopristin for treatment of invasive Gram-positive infections in pediatric patients. Pediatr Infect Dis J. 2002;21(10):950-956.

156. Olsen KM, Rebuck JA, Rupp ME. Arthralgias and myalgias related to quinupristin-dalfopristin administration. Clin Infect Dis. 2001;32(4):e83-e86.
157. Seybold U, Supthut-Schroder B, Draenert R, Hogardt M, Bogner JR. Prevalence and risk factors of nasal colonization with Staphylococcus aureus - association with HIV infection in older patients. Scand J Infect Dis. 2009;41(1):63-66.

158. Madariaga MG, Ullrich F, Swindells S. Low prevalence of community-acquired methicillin-resistant Staphylococcus aureus colonization and apparent lack of correlation with sexual behavior among HIV-infected patients in Nebraska. Clin Infect Dis. 2009;48(10):1485-1487.

159. Lu P SL, Chen T, Feng M, Chen Y. Risk factors for methicillin-resistant Staphylococcus aureus (MRSA) carriage among HIV-infected cohort in an MRSA prevalence area. XVI International AIDS Conference, Toronto, Canada, Aug 13-18, 2006; abstract CDB02792006.

160. Villacian JS, Barkham T, Earnest A, Paton NI. Prevalence of and risk factors for nasal colonization with Staphylococcus aureus among human immunodeficiency virus-positive outpatients in Singapore. Infect Control Hosp Epidemiol. 2004;25(5):438-440.

161. Padoveze MC, Tresoldi AT, von Nowakonski A, Aoki FH, Branchini ML. Nasal MRSA colonization of AIDS Patients cared for in a Brazilian university hospital. Infect Control Hosp Epidemiol. 2001; 22(12):783-785.

162. Chacko J, Kuruvila M, Bhat GK. Factors affecting the nasal carriage of methicillin-resistant Staphylococcus aureus in human immunodeficiency virus-infected patients. Indian J Med Microbiol. 2009;27(2):146-148.

\section{Publish your work in this journal}

Infection and Drug Resistance is an international, peer-reviewed openaccess journal that focuses on the optimal treatment of infection (bacterial, fungal and viral) and the development and institution of preventive strategies to minimize the development and spread of resistance. The journal is specifically concerned with the epidemiology of antibiotic

\section{Dovepress}

resistance and the mechanisms of resistance development and diffusion in both hospitals and the community. The manuscript management system is completely online and includes a very quick and fair peerreview system, which is all easy to use. Visit http://www.dovepress.com/ testimonials.php to read real quotes from published authors. 